\title{
Foreign Direct Investment in Indian Insurance Industry - An Analytical Study
}

\author{
Smt. Chandra Kantha .K, Dr. M. Ramachandra Gowda \\ Associate professor, LBS College, Bangalore, Karnataka, India \\ Professor, Department of commerce, Bangalore University, Karnataka, India.
}

\begin{abstract}
FDI plays a key role in the globalisation process in terms of financing, transferring of skills, knowledge and technology between countries. The economic reforms initiated in India in the early $90 \mathrm{~s}$ paved the way for the growth and opening up of the financial sector. Insurance and banking are the main components of finance sector. The reforms in insurance sector started in the year 2000 with the implementation of recommendations made by the Malhotra committee. Indian insurance industry was opened up for private players in the year 2000 with the enactment of IRDA Act. However to meet the capital requirement of private insurance companies the Government approved to enhance the FDI cap from $26 \%$ to $49 \%$. In the last fourteen years of period the insurance industry has moved forward on multiple fronts. At the same time the industry is faced with many challenges. On this backdrop an attempt is made to study the significance of FDI and the challenges and prospects of insurance sector during the post reforms period. It is find that liberalisation in insurance sector has brought many positive changes in the industry and at the same time it demands to strengthen CSR and Governance principles for sustainable growth in the industry.

Key words: Foreign Direct Investment, IRDA, Liberalisation, Insurance industry.
\end{abstract}

\section{INTRODUCTION:}

The insurance Industry in India has been progressing at a rapid pace since opening up of the industry in 2000. The insurance sector has become a major contributor to economic development, especially to infrastructure development. Insurance sector contributes for about $4.5 \%$ of the country's GDP. The passage of IRDA Act 1999 is the major reform in insurance sector in India. IRDA allowed foreign participation up to $26 \%$ (now it is $49 \%$ ) in equity shareholding of private companies. As a result many private companies got themselves registered with IRDA to operate in India At present 52 insurance companies (public and private sector) are operating insurance business in India. Several reforms and policy measures have enabled a favourable environment for insurance companies to flourish in the country. The growth has been supported by India's multiplying consumer class, rising insurance awareness, increasing domestic savings and investments. In the last fourteen years of period the insurance industry has moved forward on multiple fronts. At the same time the industry is faced with many challenges. The paper attempts to study the significance of FDI in Indian insurance industry

\section{OBJECTIVES OF THE STUDY:}

To study the significance of FDI in life insurance industry in India.

To analyse the opinion of insurance executives of public and private insurance companies.

\section{RESEARCH METHODOLOGY:}

The study is made on the basis of primary and secondary data. The primary data are collected through questionnaire from the executives of insurance companies. The sample size of the study was 60 , out which 40 executives are from public sector (LIC) and 20 executives are from private sector. Secondary data are collected from various sources. The main sources of secondary data are Journals, Articles, Newspapers, IRDA annual reports, The Journal of Insurance Institute of India and Annual reports of LIC. The scope of study is confines to life insurance sector in India. The primary data are taken for analysis of opinion of insurance executives and to test the hypothesis framed for the study.

\section{Hypothesis for study:}

H0 - There is no significant difference between the opinion of executives of public sector and private sector insurance companies.

H1 - There is a significant difference between the opinion of executives of public sector and private sector insurance companies.

\section{REVIEW OF LITERATURE:}

Albuqurque (2003), in his article "The composition of international capital flows" examines that global factors have increased importance in explaining FDI flows. The researchers used a large cross country time series data set to analyse the driving factors of FDI across the countries. They indentify capital market liberalisation and integration as the key driver of FDI. The study finds that global drivers are increasing in importance; however the domestic 
drivers like growth in local productivity, trade openness, financial depth and macroeconomic stability still account for a sizeable amount of inter country variation in Foreign Direct Investment.

Dr.Boonyasai (1999) In his Ph.D dissertation “ The effect of liberalisation and deregulation on life insurer efficiency", examines that competition not only leads to economic efficiency but it also improves service quality of insurers by way of innovative products at greater variety of choices for the benefit of buyer. The study covers the insurance market of Korea, The Philippines Taiwan and Thailand. It was concluded that liberalisation creates competitive market and stimulates the growth of the insurance industry.

Harsh Kapoor: in his article "FDI in insurance: For better future" focus on the Opportunities and challenges in the Indian insurance industry by analysing SWOT of insurance sector. The paper focuses on the factors which act as growth drivers of insurance industry. The study finds that rising income of middleclass, societal changes, urbanisation and financial sophistication are the major growth drivers of insurance industry.

KaveriBansal and Mona Bansal (2009): Expressed their findings in an article published in Indian Banker, that Liberalisation of the industry, resulting in growing competition and increasing number of players has made branding an essential ingredient of the insurance business. Insurance companies are leveraging upon the brand awareness and equity banks, thus enhancing customer receptiveness for insurance products.

Tapen Sinha (2004) in his article "Insurance sector in India: Towards 2020 vision" assessed macro economic trends which support for the development of insurance sector in India. In 1950, the savings and investment rate in India was around $10 \%$ of GDP and they have risen to around $25 \%$ of GDP by 2000 and there is a potential for further growth of savings and investment rates. The author examined the relation between insurance and GDP in India. A tentative conclusion of Tapen Sinha was that a rise of one percent of real GDP leads to a rise of two percent of rise in insurance demand in the context of India. The paper concludes that rising education level, technological innovations, cheaper and faster communication and globalisation are the major factors which will act as growth engines of insurance and economic development of India.

\section{FOREIGHN DIRECT INVESMENT IN INSURANCE}

Most of the economists and analysts opine that FDI helps for the economic development of the nation. 'Foreign direct Investment is profitable both to the country receiving investment and the investor. For the investor company FDI offers an exclusive opportunity to enter into the international or global business, new markets and marketing channels, elusive access to new technology and expertise, and expansion of company with new or more products or services, and cheaper production facilities. The host country receives foreign funds for development, transfer of new profitable technology, wealth of expertise and experience and increased job opportunities' (Horold D skipper, Jayaram, Chalapathi Rao -2011).

As a financial service, Insurance is an integral part of national economy and a strong pillar of financial market. Ample of studies suggests that insurance contributes materially to economic growth by improving the investment climate and promoting a more efficient mix of activities that would be undertaken in the absence of risk management instruments (Tapen Sinha 2004). Insurance serves a number of valuable economic functions that are largely distinct from the functions served by other types of financial intermediaries. United Nations Conference on Trade and Development (UNCTAD) pronounced that a sound insurance and re-insurance market is an essential characteristic of economic growth.

The waves of liberalisation, privatisation and globalisation have deeply influenced the insurance market worldwide. With the increase in Trade, Direct Investment and Portfolio Investment, there has been an ever growing demand for Insurance services particularly in the emerging markets. Globalisation of Insurance market, as a part of the overall process of liberalization in emerging and other countries enabled the foreign insurance companies to enter in those countries and benefited both. The driving forces of insurance market globalization have been identified by Swiss $\mathrm{Re}$ (Sigma No.4/2000) as the 'push factors' and 'Pull Factors'. The Push factors are the motives behind the movement of foreign insurance companies while the pull factors are the motives behind allowing the foreign companies to operate in local market.

\section{INDIAN SCENARIO}

The Indian insurance industry is more than 150 years old. It has witnessed many phases of the working from the days when there were many private sector companies initially and then moved to nationalisation and again to the private sector. The Indian insurance industry was opened for private insurers in the year 1999, with the enforcement and establishment of industrial regulatory and development authority Act (IRDA). The first stage reforms in insurance industry started with the enactment of IRDA and permitting the private players to get register to write up insurance business with FDI cap of $26 \%$ ( now it is $49 \%$ ). 
Insurance sector was privatized with objective of creating healthy competition in the industry and to meet the needs of stakeholders.

The insurance laws (Amendment) Act 2015 and hike in FDI cap from $26 \%$ to $49 \%$ is a second stage reforms in insurance sector. The Act is aimed to allow insurance companies to generate capital and to generate resources for business. The life insurance industry is capital intensive, and insurers are required to infuse capital at regular intervals to meet the expenses like, training costs for development of the distribution channels, creating niche market, expansion of branches etc.. The experience of the insurance markets globally indicates that companies in the life sector take seven to ten years to break-even .Against this backdrop there was a huge demand from private insurers to hike FDI cap from $26 \%$ to $49 \%$, and it was approved by the Government by the enactment of Insurance laws (amendment) Act 2015. The Act will also enable empowering IRDA to regulate key aspects like solvency, Investment structure, operational expenses and commissions of insurance companies.

\section{FDI IN INSURANCE AND ITS BENEFITS}

Insurance Regulatory and Development Authority permitted global insurers to setup and register a domestic company to undertake insurance business in India. However regulations stipulate that they should have a capital base of at least US \$20 million and their investment in such company is capped at 26 percent (now it is $49 \%$ ). Thus to participate in the market they must form a joint venture with an Indian partner that is able to invest the remaining funds.

The entry of private players with FDI has led to tremendous changes in Indian life insurance industry. Since opening up, the number of participants in the industry has gone up from seven insurers in the year 2000 to 52 insurers in 2014, operating in the life, non-life and re-insurance segments. As at the end of September 2014, there are 24 life insurance companies operating in India, of which one is LIC the state owned Life Insurance Corporation and the remaining 23 are in private sector. The given table shows total amount of FDI inflows in insurance sector.

Table 1. EQUITY CAPITAL OF LIFE INSURERS IN INDIA

(Rs. Crore)

\begin{tabular}{|c|c|c|c|c|c|}
\hline INSURER & \multicolumn{2}{|c|}{ PUBLIC (LIC) } & \multicolumn{2}{c|}{ PRIVATE INSURERS } & $\begin{array}{c}\text { (FDI - 23\% to 26\% } \\
\text { of capital) }\end{array}$ \\
\hline YEAR & $\begin{array}{c}\text { CAPITAL } \\
\text { (in crore) }\end{array}$ & ADDITONS & $\begin{array}{c}\text { CAPITAL } \\
\text { (in crore) }\end{array}$ & ADDITONS & FDI \\
\hline $\mathbf{2 0 0 5 - 0 6}$ & 5.00 & - & 5887.05 & 1539.24 & $\mathbf{1 3 5 5 . 3 5}$ \\
\hline $\mathbf{2 0 0 6 - 0 7}$ & 5.00 & - & 8119.41 & 2232.36 & $\mathbf{1 8 0 9 . 7 5}$ \\
\hline $\mathbf{2 0 0 7 - 0 8}$ & 5.00 & - & 12291.42 & 3787.01 & $\mathbf{2 8 2 1 . 6 3}$ \\
\hline $\mathbf{2 0 0 8 - 0 9}$ & 5.00 & - & 18248.04 & 5956.62 & $\mathbf{4 3 5 4 . 5 0}$ \\
\hline $\mathbf{2 0 0 9 - 1 0}$ & 5.00 & - & 21014.99 & 2765.22 & $\mathbf{5 0 5 3 . 9 8}$ \\
\hline $\mathbf{2 0 1 0 - 1 1}$ & 5.00 & 95.00 & 23656.85 & 2641.86 & $\mathbf{5 7 2 3 . 8 1}$ \\
\hline $\mathbf{2 0 1 1 - 1 2}$ & 100.00 & - & 24831.92 & 1175.07 & $\mathbf{6 3 2 4 . 2 7}$ \\
\hline $\mathbf{2 0 1 2 - 1 3}$ & 100.00 & - & 25418.73 & 586.80 & $\mathbf{6 0 4 5 . 9 1}$ \\
\hline $\mathbf{2 0 1 3 - 1 4}$ & 100.00 & - & 25838.51 & 419.78 & $\mathbf{6 1 1 3 . 3 8}$ \\
\hline
\end{tabular}

Sources: Annual reports of IRDA 
Graph-1: FDI inflows in Indian Life insurance

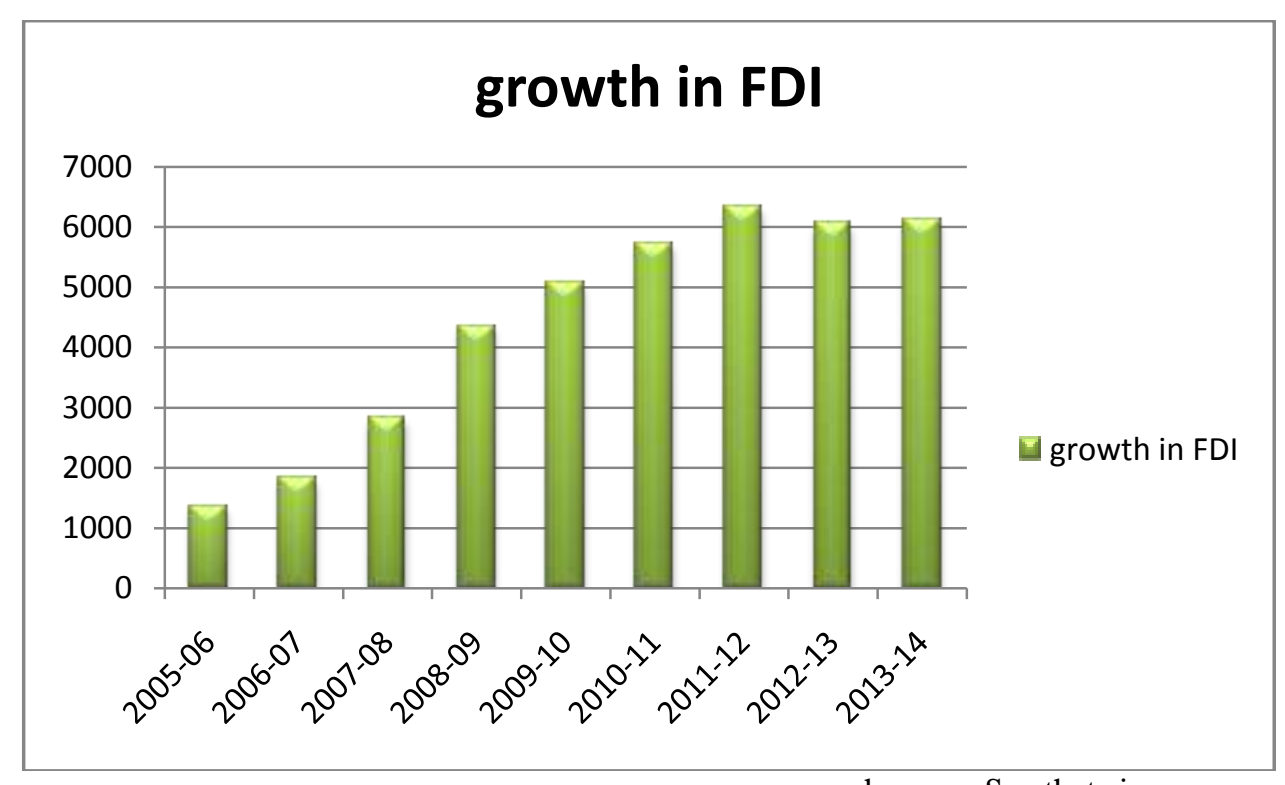

The above table reflects that FDI inflows are attractive in the beginning period of liberalisation. The amount of FDI inflows gradually reduced from the period of 2009-10. This may be due to the declining economy growth and persistent high rate of inflation. Despite continuous efforts made by the Government and IRDA, the growth in the industry is sluggish and penetration is still at $3.10 \%$. So there is a need for further expansion of insurance business in the country and which requires huge amount of capital along with regulatory measures. On $10^{\text {th }}$ July 2014 the finance minister $\mathrm{Mr}$. ArunJaitly announced in his first union budget 2014-15 to increase the FDI limit from $26 \%$ to $49 \%$, with full Indian management control through Foreign Investment Promotion (FIPB) route. On $26^{\text {th }}$ December 2014 Government has passed the insurance laws (amendment) Act 2015. On $23^{\text {rd }}$ March 2015 the Government notified the insurance laws (amendment) Act 2015. Hike in the FDI cap from $26 \%$ to $49 \%$ management "controlled" by Indians is one among the major amendments made in insurance laws. Hike in FDI will benefits the Industry in the following ways.

1. Availability of increased capital inflow will enable the insurers to cover untapped population of urban and rural areas. Capital infusion helps to invest in branch expansion, H R training, wide distribution channel to promote insurance products.

2. Along with Capital insurance companies will get the benefit of improved technology, advanced managerial skills and market efficiency to meet the competitive environment of the industry.

3. The experience and expertise of foreign companies could be utilized to promote insurance business through social security schemes. So that insurers could easily reach the rural mass to meet the CSR guidelines of IRDA.

4. FDI will bring a degree of comfort and ease to the foreign partners. FDI benefits the insurance sector in terms of product innovation, innovative distribution channels, and spread of insurance message by educating the society at large.

5. FDI leads to growth in insurance sector and further leads to capital formation, employment generation and increase in productivity.

With several reforms and policy regulations the insurance industry in India experienced substantial growth in terms of numbers, insurance premium, insurance penetration, number of products, distribution channels etc. Due to the growing demand for insurance more and more insurance companies are entering into the Indian insurance sector and creating competitive environment in the industry. Customers are privileged with product innovation and technological advancement. However the study reveals that there is a significant difference between the opinion of public sector insurance company executives and the opinion of private sector insurance company executives about FDI in life insureance.

\section{DATA ANALYSIS AND FINDINGS}

The primary data collected through Likert Scale questionnaire are tabulated with mean values for the purpose application of T-test and to compare the views of executives of public and private sector insurance companies. T-test is a parametric test, to test whether the average (mean) of two populations are the same. When the sample size is less, t-test is the most appropriate technique to analyze the data. 


\begin{tabular}{|c|c|c|c|}
\hline SL.NO & VARIABLES & PUBLIC, N=40 & PRIVATE, $\mathbf{N}=20$ \\
\hline 1 & $\begin{array}{l}\text { F D I MEETS CAPITAL REQUIREMENTS OF } \\
\text { INSURANCE COMPANIES }\end{array}$ & 2.33 & 4.6 \\
\hline 2 & $\begin{array}{l}\text { F D I EMERGED WITH TECHNICAL AND } \\
\text { MANAGERIAL SKILLS }\end{array}$ & 2.53 & 4.35 \\
\hline 3 & $\begin{array}{l}\text { FOREIGN PLAYERS (PRIVATE COMPANIES) } \\
\text { ARE CREATING A GOOD COMPETITION }\end{array}$ & 1.95 & 4.4 \\
\hline 4 & $\begin{array}{l}\text { HIKE IN FDI CAP FROM } 26 \% \text { TO } 49 \% \text { WILL } \\
\text { FURTHER BOOST THE BUSINESS }\end{array}$ & 2.30 & 5.05 \\
\hline 5 & $\begin{array}{l}\text { PRIVATE PLAYERS WITH FDI WILL } \\
\text { CONTRIBUTE FOR THE ECONOMIC } \\
\text { GROWTH (INFRASTRUCTURE) }\end{array}$ & 2.03 & 4.35 \\
\hline 6 & $\begin{array}{l}\text { FDI AND THE ENTRY OF PRIVATE PLAYERS } \\
\text { HAS IMPROVED THE INSURANCE } \\
\text { PENETRATION }\end{array}$ & 3.32 & 3.9 \\
\hline 7 & $\begin{array}{l}\text { PRIVATE PLAYERS WILL DOMINATE THE } \\
\text { MARKET }\end{array}$ & 2.55 & 3.45 \\
\hline 8 & $\begin{array}{l}\text { PRIVATISATION OF INSURANCE WITH } \\
\text { FOREIGN PARTNERS WILL AFFECT THE } \\
\text { INTEREST OF POLICYHOLDERS }\end{array}$ & 3.15 & 4.30 \\
\hline & TOTAL & 20.16 & 34.4 \\
\hline
\end{tabular}

The value of $\mathbf{t}$ is calculated by using the given equation.

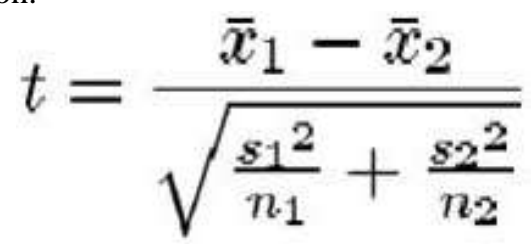

where $\overline{\mathrm{x}}_{1}=$ mean of sample 1

$\overline{\mathrm{x}}_{2}=$ mean of sample 2

$\mathrm{n}_{1}=$ number of subjects in sample 1

$\mathrm{n}_{2}=$ number of subjects in sample 2

$s_{1}^{2}=$ variance of sample $1=\frac{\sum\left(\mathrm{x}_{1}-\overline{\mathrm{x}}_{1}\right)^{2}}{\mathrm{n}_{1}}$

$\mathrm{s}_{2}{ }^{2}=$ variance of sample $2=\frac{\sum\left(\mathrm{x}_{2}-\overline{\mathrm{x}}_{2}\right)^{2}}{\mathrm{n}_{2}}$

SAMPLE - 1

\section{$\mathbf{X}=\mathbf{2 . 5 2}(\mathrm{MEAN}$ VALUE)}

SAMPLE - 2

$\mathbf{X}=\mathbf{4 . 3}$ (MEAN VALUE)

When the values are substituted for the above equation, t- value will be - $\mathbf{T}=\mathbf{1 2 . 7 1}$

Where S D for Sample $1=1.31$ and S D for Sample 2=1.24

Significance at 5\%, df-14, Table value $=2.145$.

As the calculated values is more than the table value, the Null Hypothesis is rejected and alternative hypothesis is accepted which means there is a significant differs in the opinion of executives of public sector insurance companies and private sector insurance companies. The study reveals that Executives of Private sector insurance are in favour of FDI and they opine that hike in FDI will further boost the industry, whereas in public sector only a few Executives are in favour of FDI in insurance.

\section{CONCLUSION:}

Life insurance industry is different from other financial services as it needs to have a long term relationship with its customers. Moreover the life insurance business is highly complex with the evolving statutory regulations. Foreign Direct Investment in insurance may bring product innovation and technological innovation but at the same time it brings a Plethora of risks. An unwarranted increase in the number of private players in the industry will inevitably exposes the country to risks. Policy makers have the most important role to play. Increase in size of foreign holding should not be open to all insurers; there should be some criteria and strategies in liberalizing FDI polices. The Regulatory body IRDA has been empowered with the insurance laws (amendment) Act - 2015 and it is time to execute its powers in order to monitor and regulate the insurance industry in the interest of policy holders and other stakeholders of the industry.

\section{References:}

1. Alburqurque (2003) The composition of international capital flows-Risk sharing through FDI - Journal of international economics Vol61, 2003

2. Ashvin parekh \& chandajit banergee (2010) Indian Insurance sector-stepping into the next decade of growth.

3. Dr. Boonyasai T. (1999) The effect of liberalisation and deregulation on life insurance efficiency- Ph.D dissertation, George State University.

4. Dr. S A Saiyed (2012) Effect of FDI on Economic Growth in India. PARIPEX Indian journal of Research. PP 25-28.

5. Deloitte: (2011) Indian insurance sector - innovate now or stagnate - A report 
6. Horld D Skipper(1997), Foreign insurers in emerging markets- issues and concerns- Washington, International insurance foundation

7. Harsh Kapoor- (2012) "FDI in insurance: For better future

8. Kishore kumar meena (2011) FDI in life insurance companies.

9. K s Chalapati Rao \& Biswajit Dhas (2011) India's FDI inflows trends.

10. Mahantha Devajit (2012) Impact of FDI on Indian economy, Research Journal of Management Sceinec. PP 29-31.
11. IRDA Journal - The insurance laws (amendment) Act 2015 March 2015.

12. IRDA Annual reports

13. R Rajendran and B Natarajan (2010) The impact of liberalization, privatization and globalization on life insurance corporation of India.

14. Rebecca.c.amoroso (2012) Global insurance outlook. Generating growth in a challenging economy takes operational excellence and innovation- A report by Deloitte.

15. Tapen Sinha (2004) Insurance sector in India towards 2020 vision. A report 